\title{
Analyses of the Present Situation of Social Commerce Research in China
}

\author{
Wang Shucui \\ Alibaba Business School \\ Hangzhou Normal University \\ Hangzhou, China \\ wangsc2003@126.com
}

\author{
Zhao Hong \\ Alibaba Business School \\ Hangzhou Normal University \\ Hangzhou, China \\ zhhong2008@163.com
}

\author{
Suo Jiacen \\ Alibaba Business School \\ Hangzhou Normal University \\ Hangzhou, China \\ maxsuo@stu.hznu.edu.cn
}

\begin{abstract}
In order to ensure the sustainable development of social commerce in the future, this paper, based on the connotation of social commerce and the development of social commerce in the past more than $\mathbf{1 0}$ years, we comb the Chinese and foreign academic literature from the differences between social commerce and traditional electronic commerce and the classification of social commerce. Our country is in the rapid development stage of social commerce. By researching the user acceptance of social commerce, the business model, and the information service, we summarize the current research status of social commerce, and provide theoretical feasibility suggestions for the sustainable development of social commerce in China.
\end{abstract}

Keywords-social commerce; social media; e-commerce; research status

\section{INTRODUCTION}

Yahoo first proposed the term social commerce in December 2005, the term began to be introduced into the academic community in 2007. The research on social commerce in China is still in its infancy. The systematic and comprehensive study of social commerce began in 2011. In recent years, a large number of literature studies began to appear, but there are still no mature theoretical system and research results. This research has carried on the analysis work through the retrieval and the reorganization existing literature. The search source of English literature is mainly based on the Web of Science foreign language database, and the retrieval source of Chinese literature is based on CNKI journal database and Wan Fang database.

At present, scholars use different terms to interpret "social media" + "e-commerce", but the object of study is the same emerging phenomenon. Therefore, we determine that the definition of research object in this paper is social commerce.

\section{The Connotation of SOCial COMMERCE}

\section{A. The Meaning of Social Commerce}

Scholars have divergent views on what is social commerce.
Ma Ling [1] and others believe that social commerce is a special form of e-commerce. Foreign scholars Rad [2] and others also tend to think that social commerce is a new form of e-commerce. But social commerce emphasizes the possibility of discussion among users, and the evaluation of goods and service. Tian Yuqing [3], Wu Juhua [4], Xu Guohu [5] and others believe that social commerce can provide service to users and ultimately improve the conversion rate of transactions. Some scholars believe that social commerce is the process of using social media technology to influence users to make decisions, and it focuses on the impact of social media on business activities. In social media context, Zong Qianjin argued, social commerce is the business model that promotes product or service by integrating social graph based on interpersonal interaction and interest graph based on the interaction of information flow [6].

Therefore, there is no standard, unified definition of social commerce at present. In general, social commerce is defined as the use of Internet media, enabling users to participate in sales, purchase and comparison, and in the online market and community products and services for information sharing. We believe that it is e-commerce delivery activities and service through web 2.0 in the social media environment, mainly on social networking sites. Thus, social commerce can be seen as a subset of e-commerce, which needs to take advantage of social media to help with e-commerce transactions and activities. At the same time, it also supports social interaction and user content contributions. But in essence, it is a combination of e-commerce and social networking. So how to take advantage of new form of e-commerce is a challenging problem.

\section{B. The Difference between Social Commerce and E- commerce}

Although social commerce is a derivative model of traditional electronic commerce, social commerce and e-commerce are different in essence. The difference between social commerce and traditional e-commerce is becoming increasingly apparent as social interactions are gradually unfolding in the media. By collating the research results of 
existing scholars, the difference is mainly embodied in the "social". It means that social commerce pays more attention to human factors, and it can exert the influence of interpersonal relationship by establishing the network between users and users. For details, see Table I below:

TABLE I. DIFFERENCES BETWEEN SOCIAL COMMERCE AND E-COMMERCE

\begin{tabular}{|c|c|c|}
\hline Elements & $\begin{array}{c}\text { Traditional } \\
\text { E-commerce }\end{array}$ & Social Commerce \\
\hline $\begin{array}{l}\text { Interpersonal } \\
\text { Interaction }\end{array}$ & $\begin{array}{l}\text { It is more reflected in } \\
\text { the user to publish and } \\
\text { read online comments }\end{array}$ & $\begin{array}{l}\text { It takes interpersonal } \\
\text { interaction as its core, } \\
\text { and carries out business } \\
\text { activities based on the } \\
\text { network between users. }\end{array}$ \\
\hline Social Media & $\begin{array}{l}\text { It hardly involves } \\
\text { social media }\end{array}$ & $\begin{array}{l}\text { It attaches importance to } \\
\text { social media, and it } \\
\text { builds a network of } \\
\text { relationships through } \\
\text { social media to increase } \\
\text { user stickiness } \\
\end{array}$ \\
\hline Commercial Intent & $\begin{array}{l}\text { It relies on sale } \\
\text { quantity to measure } \\
\text { performance and to win } \\
\text { competitive advantage } \\
\text { by commodity prices }\end{array}$ & $\begin{array}{l}\text { It relies on the sharing of } \\
\text { information and } \\
\text { experience to measure } \\
\text { performance, to gain } \\
\text { competitive advantage } \\
\text { by the value of the } \\
\text { product }\end{array}$ \\
\hline Information Flow & $\begin{array}{l}\text { It relies mainly on the } \\
\text { one-way spread of } \\
\text { commercial } \\
\text { broadcasting }\end{array}$ & $\begin{array}{l}\text { It emphasizes user } \\
\text { contributions and } \\
\text { user-generated content, } \\
\text { and it uses a two-way } \\
\text { communication } \\
\text { approach to the } \\
\text { infiltration of } \\
\text { interpersonal } \\
\text { communication }\end{array}$ \\
\hline
\end{tabular}

\section{ClassificAtion OF SOCIAL COMMERCE}

In general, social commerce is a collection of social media and e-commerce. Social commerce website also gives full play to functions of social media and e-commerce. It is presented in different forms, and scholars have classified them from different perspectives. Since 2011, social commerce in China has entered a period of rapid development, and the classification of social commerce sites is becoming clearer. On the whole, this paper holds that there are three types of social commerce: social commerce platform based on e-commerce, social commerce platform based on social networking site and third-party independent social commerce platform.

\section{A. Social Commerce Platform Based on E-commerce}

The social commerce platform based on e-commerce refers to the application of social media functions to e- commerce. The main business of this kind of website still is to improve the sales of products or service. In recent years, domestic e-commerce has developed rapidly. The competition among e-commerce sites is also getting fiercer, and marketing costs are increasing. And transaction conversion rate is gradually reduces, user traffic is decentralized, and user viscosity is difficult to guarantee. These have become the problem that the electronic commerce urgently to be solved. As a result, e-commerce has begun to introduce its existing consumers and potential consumers into their own social networks in an incentive way. Social networking is built to support the development of the main business and to conform to the trends of social commerce. Social networking is just built to support the development of the main business and to conform to the development trend of social commerce. E-commerce websites mainly utilize the community function to increase the user interaction, and it enhances user purchase intention and user loyalty through the strong relationship between users. To some extent, social commerce platform can improve profitability for sites, but it still has a great commercial color. So it has limited role in improving user loyalty, and it can't give full play to "social" advantage of social media. Moreover, the main users of this type of social commerce platform are still registered users of e-commerce sites, and user traffic increase doesn't change significantly. This kind of representative is Taojianghu.

\section{B. Social Commerce Platform Based on Social Networking Site}

Social commerce platform based on social networking refers to the application of e-commerce in social networking sites. The main business of this kind of websites is still for the user interaction service. The network of strong relationships among users in social networking sites forms a low-cost marketing channel for e-commerce marketing. The frequent interaction between users has greatly improved the user trust degree and stickiness of the social commerce platform. But since the main business of social networking sites is not sales of goods, excessive advertisements may cause the user's resentment, thereby reducing the user satisfaction. As a result, the social commerce platform needs to integrate community-owned user resources and social graph without reducing the user experience and abandoning social intent, and through the social resources to support the development of e-commerce. This kind of representative is Nuomi Net.

\section{The Third-party Independent Social Commerce Platform}

The third-party independent social commerce platform is the social network and the electronic Commerce coordinated development. This kind of social commerce platform mainly attracts users with common interests, and users with the same hobbies can quickly build social relationships through interest discussions and experience sharing. This social relationship, based on common interest, is more likely to be sustained over time and extended outward to expand the network. For the platform, this is beneficial for obtaining a large number of loyal users, and it can effectively tap the potential needs of consumers. At present, third-party independent social commerce website mainly include: Meilishuo, Mushroom Street and so on.

\section{RESEARCH AND ANALYSES ON CURRENT SitUATION OF SOCIAL COMMERCE}

The main components of social commerce are users, organizations and information. User is the core driving factor in the development of social commerce platform, and the user activity is the strong support of the social commerce platform to attract the merchants. And information is the source of the value creation of social commerce platform; it is the signal transmission between users. And organization and user are the producer of information. Organizations, including enterprises, sellers and social media operators, are important participants and stakeholders in social commerce. Users, organizations and information are linked through social commerce websites, and information is created through interactions between users. And 
organizations provide users with personalized differentiated services to improve customer satisfaction of the social commerce platform.

\section{A. Research on User Acceptance Intention of Social Commerce}

The advantage of social commerce is to seamlessly connect e-commerce with social media, giving users the new experience. In order to promote the user interaction and participation, we need to understand the motivations of user interaction and participation, Zhao Dan divided the user participation motivation into the material level and the spirit level[7]. Social commerce influences the buying behavior of users through social media, and interaction among members of the community also can affect the behavior of members in the group [8]. Based on the social media network, adding user and user, user and social commerce platform interaction can promote continuance of users. Through the intermediary effect of self-efficacy and virtual community, users can indirectly influence the stickiness of users [9]. Li Guoxin and others believed that the social commerce websites, which is high community viscosity, can promote deeper participation of users, and the higher the conversion rate of transaction [10]. Social media as a means of social commerce platform, its ultimate goal is to serve the e-commerce, improve the stickiness of users, and ensure the profitability of social commerce platform and stakeholders. As the way to obtain the information of the goods, the word-of-mouth effect can gain the trust of other users and influence the purchasing intention of the consumers. The main form of word-of-mouth communication is the online evaluation of consumers. And positive evaluation will increase the desire of potential consumers to purchase products, but the correct handling of negative evaluation can also increase the willingness of consumers to buy back[11].

\section{B. Research on Business Model of Social Commerce}

The benign operation of the social commerce platform benefits from its business model, and the business model of e-commerce has not adapted to the development of social commerce. As a result, social commerce platform continues to innovate in business model, while academics are also actively studying business model innovation. From the perspective of the business focus of social commerce, $\mathrm{Xu}$ Guohu and others divided the business model of social commerce into three varieties from the business focus of social commerce: social media based on e-commerce website, adding e-commerce to social media, social media and e-business collaborative development [5]. Wu Juhua and others focused on the changes in the business model of social commerce and e-commerce, and combed the innovation of the social commerce model [4]. Du Lu and others took Meilishuo as an example; they analyzed the experience of users of social commerce websites from five levels. And they researched social commerce from the perspective of the user experience [12]. Guo Hao analyzed the profit model of the social commerce platform and divided the profit model of social commerce into: advertising revenue, commission, value-added service charges and third-party plug-in application, etc., and they pointed out the three kinds of social commerce profit model innovation [13].

\section{Research on the Information Service of Social Commerce}

The social commerce information service mainly refers to advertisements, the commodity service information as well as user generated content (UGC). User generated content mainly includes word-of-mouth dissemination, value-creating, user interaction and so on. Social commerce pays more attention to user generated content, and social commerce makes use of platform to communicate with the users in a two-way communication. As the main body of social commerce, users are not only the media of information dissemination, but also the source of information production [14]. By studying the Xiaomi company's value of user participation to create, Yang Xuecheng and others demonstrated the importance of information and user engagement in the process of value creation[15]. Tao Xiaobo believed that information should be seen as a source of enterprise value creation [16]. Under the background of social commerce, Chen Yuan and others constructed the business information service model based on social media. In order to achieve the purpose of realizing business information interaction, they used SNS principle to construct social commerce platform and enterprise social network system platform for individual and organization users respectively [17].

\section{CONCLUSION AND PROSPECT}

From the research status of social commerce, the following characteristics are found in the research results: First, compared with the research of user behavior, there are relatively few studies on business model and information. Second, the focus of the study began to shift to "socialization". Third, the homogenization of research methods.

In summary, the academia in the future can study the social commerce from the following aspects: (1) At present, the research on the effect of social commerce communication is widely used in questionnaire survey, data is easy to distort. In later research, we can try to verify the communication effect of social commerce by simulation experiment. (2) In the study of user acceptance intention of social commerce, the element of "socialization" is paid more and more attention. However, the research on this element is limited to social support and social participation. In future studies, we can introduce the appropriate theories in other fields, and deeply analyze the expressive factor of social commerce "socialization". (3) In view of the homogenization of current research methods, future scholars can try to diversify their research methods.

\section{REFERENCES}

[1] M. Ling, X. Yun, C.Haotian, Analysis of the Present Situation and Tendency of Social Commerce in Chian, Modern Business Industry, pp.167-168, May 2014.(In Chinese)

[2] Afrasiabi Rad A, Benyoucef M, A Model for Understanding Social Commerce, Journal of Information Systems Applied Research,vol.4, pp.63-73, February 2011.

[3] T.Yuqing, Overview of Social Commerce Research, Journal of Beijing University of Posts and Telecommunications: Social Science Edition, vol.15, pp.32-39, April 2013.(In Chinese)

[4] W.Juhua,G.Sui,M.Zan, Research on the Innovation of SocialCommerce Model, Information Science,vol.32, pp.48-66, Decdmber 2014.(In Chinese)

[5] X.Guohu, H.Xue, Analysis of the Value Chain of Social Commerce Industry, Journal of Wuhan University of Technology: Social Science Edition,vol.27, pp.59-65, January 2014.(In Chinese) 
[6] Z.Qianjin, A Summary of Overseas Social Commerce Research, Information magazine, pp.117-121, October 2013.(In Chinese)

[7] Z.Dan, The Differences and Synergy of Social Commerce Means - A Model Framework, Enterprise Economy,pp.67-69, June 2016.(In Chinese)

[8] S.Yi, L.Yaobin, W.Guoji, The Influence of Social Atmosphere on the Willingness and Behavior of Friends Group Members, Journal of Management, vol.13, pp.1392-1399, September 2016.(In Chinese)

[9] Z.Junjie. User 's Stickiness in the Context of Social Commerce: Indirect Influence and Adjustment of User Interaction, Management Review, pp.127-136, July 2015.(In Chinese)

[10] L.Guoxin, L.Yijun, N.Fei, An Empirical Study on Virtual Community E - commerce Based on User 's Online Trading Intention, Management Review, vol.23, pp.80-88, August 2011.(In Chinese)

[11] L.Yunfan, L.Yaobin, L.Jiabao,and so on, Research on Customer Online Communication in Social Commerce: Influencing Factors and Law of Action, Management Review, vol.26, pp.111-121, April 2014.(In Chinese)
[12] D.Lu, Z.Xia, Research on UGC Type Model of Social Commerce Website Based on User Experience,Design, pp.82-84, April 2014.(In Chinese)

[13] G.Hao, Analysis on the Profit Model of Social Commerce in China, Chinese and Foreign Entrepreneurs, pp.72-73, July 2012.(In Chinese)

[14] T.Xiaobo, Y.Xuecheng, X.Yan, Review and Prospect of Social Commerce Research, Management Review, vol.27, pp.75-85, November 2015.(In Chinese)

[15] Y.Xuecheng, T.Xiaobo, From Entity Value Chain, Value Matrix to Flexible Value Network - A Case Study of the Social Value of Xiaomi Company,Management Review, vol.27, pp.232-240, July 2015.(In Chinese)

[16] T.Xiaobo, A Study on the Value of Social Commerce Background From the Perspective of Flexible Value Network,Management World, pp.170-171, August 2015.(In Chinese)

[17] C.Yuan, W.Feifei, An Analysis of Business Information Service Mode in Social Network Environment, Information and Documentation Services, pp.73-77, February 2012.(In Chinese) 